\title{
PENGEMBANGAN MEDIA PEMBELAJARAN BERBASIS MULTIMEDIA PADA MATA PELAJARAN IPA DI SMP
}

\author{
Tumbur Simangunsong ${ }^{1}$ dan Mukhtar ${ }^{2}$ \\ SMP Negeri 1 Silau Laut Kabupaten Asahan ${ }^{1}$ dan Universitas Negeri Medan ${ }^{2}$ \\ tumbursimangunson@gmail.com ${ }^{l}$
}

\begin{abstract}
Abstrak: Penelitian ini bertujuan untuk; (1) Menghasilkan video pembelajaran yang layak digunakan dan mempunyai daya tarik, mudah dipelajari dan dapat dipakai untuk pembelajaran individual, (2) Mengetahui keefektifan video pembelajaran yang dikembangkan pada mata pelajaran IPA Terpadu. Jenis penelitian ini adalah penelitian dan pengembangan yang menggunakan model pengembangan produk Borg dan Gall yang dipadu dengan model pengembangan pembelajaran Dick dan Carey. Hasil penelitian menunjukkan; (1) bahwa 88\% guru dan 100\% siswa menyatakan membutuhkan media video (2) uji ahli materi mata pelajaran IPA Terpadu berada pada kualifikasi sangat baik (87,77\%), (3) uji ahli media pembelajaran berada pada kualifikasi sangat baik (85,47\%), (4) uji coba perorangan berada pada kualifikasi sangat baik (95,79\%), (5) uji coba kelompok kecil berada pada kualifikasi sangat baik (92,87\%), (6) uji coba lapangan berada pada kualifikasi sangat baik (97.23\%). Dilanjutkan dengan uji keefektifan produk yang dibelajarkan dengan media pembelajaran berbasis audio visual (video) dengan efektifitas $81,58 \%$ dengan kategori sangat tinggi. Dengan demikian Media pembelajaran berbasis multimedia yang dikembangkan pada mata pelajaran IPA layak dan efektif untuk digunakan.
\end{abstract}

Kata Kunci : media pembelajaran, multimedia, ipa terpadu

Abstract: This study aims to; (1) Produce video learning proper use and has appeal, easy to learn and can be used for individual learning, (2) Determine the effectiveness of instructional videos developed in science subjects integrated. This research is a research and development using the model of product development Borg and Gall combined with learning development model Dick and Carey. The results showed; (1) that $88 \%$ of teachers and $100 \%$ of students stated need of video media (2) subject matter expert test Integrated IPA is at a very good qualifying (87.77\%), (3) test the learning media experts are in excellent qualifications (85.47\%), (4) individual testing are at a very good qualifying (95.79\%), (5) testing small groups are at a very good qualifying (92.87\%), (6) field trials are the excellent qualifications (97.23\%). Followed by testing the effectiveness of the products that learned with audio-visual media based learning (video) with effectiveness of $81.58 \%$ with a very high category. Thus Media multimedia-based learning developed in science subjects feasible and effective to use.

Keywords: learning media, multimedia, integrated ipa

\section{PENDAHULUAN}

Tuntutan dan tantangan pembelajaran pada saat ini semakin kompleks, karena harus berpacu dengan perkembangan ilmu pengetahuan dan teknologi yang makin pesat, dengan komunikasi canggih tanpa mengenal batas negara dan diiringi dinamika persaingan global yang kompetitif. Untuk menyikapi keadaan ini, praktisi pendidikan harus menjalankan dinamika pendidikan nasional yang kondusif dan bertahan hidup layak secara berkelanjutan di tengah-tengah persaingan global tersebut.

Untuk itu di dalam pembelajaran dibutuhkan komunikasi yang baik dalam penyaluran pesan. Pesan tersebut biasanya merupakan isi dari suatu pokok pembelajaran. Pesan tersebut disampaikan oleh guru kepada siswa melalui suatu media dengan menggunakan prosedur pembelajaran tertentu. Dalam sistem pembelajaran modern saat ini, siswa tidak hanya berperan sebagai komunikan atau penerima pesan, tetapi dapat berbalik 
fungsi, siswa bertindak sebagai komunikator atau penyampai pesan. Dalam kondisi seperti ini, maka akan terjadi komunikasi dua arah. Suatu kegiatan pembelajaran membutuhkan media untuk meningkatkan keefektifan pencapaian tujuan/kompetensi. Proses pembelajaran tersebut akan terjadi apabila ada komunikasi antara penerima pesan dengan sumber/penyalur pesan lewat media.

Pembelajaran adalah suatu kegiatan kompleks. Pembelajaran pada hakikatnya tidak hanya sekedar menyampaikan pesan tetapi juga merupakan aktivitas profesional yang menuntut guru dapat menggunakan keterampilan dasar mengajar secara terpadu dan menciptakan situasi efisien serta menciptakan suasana yang kondusif dan strategi belajar yang menarik minat siswa.

Tujuan pembelajaran yang dilakukan di sekolah-sekolah secara umum adalah untuk mentransfer ilmu dalam bentuk pengetahuan maupun keterampilan kepada peserta didik melalui berbagai proses. Proses pembelajaran yang dilakukan dengan berbagai metode untuk mencapai tujuan tersebut tidak selalu cocok pada semua siswa. Penyebabnya bisa saja karena latar belakang pendidikan siswa, kebiasaan belajar, minat, sarana, lingkungan belajar, metode rnengajar guru, dan sebagainya.

Menurut Sumadi Suryabrata (2005 : 227) bahwa masalah mendidik adalah masalah setiap orang, karena setiap orang sejak dahulu hingga sekarang, berusaha mendidik anakanaknya dan atau anak-anak lain yang diserahkan kepadanya untuk dididik. Demikian pula masalah belajar dan mengajar yang dapat dikatakan sebagai tindak pelaksanaan usaha pendidikan,adalah masalah setiap orang. Untuk itu maka perlu dan penting menjelaskan dan merumuskan masalah belajar, terutama bagi kita kaum pendidik profesional, supaya kita dapat menempuhnya dengan lebih efisien, seefektif mungkin.

Belajar menurut teori belajar konstruktivisme adalah sebagai proses di mana peserta didik secara aktif membangun ide-ide baru atau konsep berdasarkan pengetahuan saat ini dan masa lalu atau pengalaman. Belajar juga merupakan proses membangun pengetahuan sendiri dari pengalaman sendiri." Guru bertindak sebagai fasilitator yang mendorong siswa untuk menemukan prinsip-prinsip untuk diri mereka sendiri dan untuk membangun pengetahuan dengan bekerja untuk memecahkan berbagai masalah secara realistis.

Belajar adalah aktivitas manusia yang sangat luas dan bersegi banyak sehingga tidak dapat dikontrol dengan medium atau metode tunggal manapun. Sebaliknya, semua media dan semua metode dapat memberi sumbangan pada pembelajaran pada satu waktu atau pada waktu lainnya dengan cara mereka sendiri jika digunakan secara tepat. (Dave. M, 2005 ; 257). Tidak ada metode atau media buruk yang dapat mempercepat dan meningkatkan pembelajaran. Tidak ada media atau metode baik yang tidak mempercepat dan meningkatkan pembelajaran

Keberhasilan belajar siswa ditentukan oleh banyak faktor pendukung, diantaranya adalah pemanfaatan media belajar yang baik. Menurut Nana Sudjana dalam Pupuh. F (2007 ; 66) bahwa dalam proses pembelajaran media dapat berfungsi sebagai : (1) alat bantu untuk mewujudkan situasi belajar mengajar yang efektif, (2) merupakan bagian yang integral dari keseluruhan situasi mengajar yang berarti salah satu unsur yang harus dikembangkan, (3) bukan semata-mata sebagai alat hiburan yang digunakan hanaya sekedar melengkapi proses belajar mengajar supaya lebih menarik perhatian siswa, (4) lebih diutamakan untuk mempercepat proses belajar mengajar dan membantu siswa dalam menangkap pengertian yang diberikan guru, (5) penggunaan media dalam pembelajaran diutamakan untuk mempertinggi mutu belajar mengajar.

Seorang guru, di dalam melaksanakan kompetesi pedagogik dituntut untuk memiliki kemampuan secara metodologis dalam hal perancangan dan pelaksanaan pembelajaran. Termasuk di dalamnya penguasaan, pemanfaatan dan penciptaan media pembelajaran yang sesuai. Penggunaan media pembelajaran disadari akan sangat membantu aktivitas pembelajaran, baik di dalam maupun di luar kelas.

Melihat perkembangan ilmu dan teknologi, pembelajaran secara umum ikut terpengaruh oleh adanya perkembangan dan penemuan-penemuan dalam bidang keterampilan dan teknologi tersebut. Pengaruh perkembangan tersebut nampak jelas dalam upaya-upaya pembaharuan sistem pendidikan dan pembelajaran. Untuk itu, media pembelajaran menjadi suatu bidang yang harus dikuasai oleh setiap guru profesional. 
Selama ini proses pembelajaran IPA masih bersifat mekanistik ( cendrung teoretis, teacher centered, transferring). Dalam proses pembelajaran, jarang guru mengaitkan materi yang diajarkan dengan situasi dunia nyata dan jarang mendorong siswa membuat hubungan antara pengetahuan yang dimilikinya dengan penerapannya dalam kehidupan mereka seharihari. Kaitannya dengan masalah-masalah yang disajikan dalam pembelajaran sains, selama ini cendrung berorientasi pada masalah-masalah akademis yang sifatnya tertutup, jarang dikaitkan dengan konteknya. Demikian juga dalam kegiatan pembelajaran yang dirancang guru, belum menekankan pada keterampilan siswa untuk berargumentasi menggunakan penalaran sehingga siswa belum mampu mengungkapkan gagasan/ide-ide nya, baik secara lisan maupun tertulis. Hal ini tentunya akan berdampak pada rendahnya hasil belajar siswa.

Hasil observasi dan wawancara dengan beberapa guru di SMP Negeri 1 Silau Laut Kabupaten Asahan menunjukkan bahwa $88 \%$ dari guru-guru membutuhkan media pembelajaran berbasis video dalam proses pembelajaran agar proses pembelajaran lebih efektif dan efisien. Secara khusus informasi dari guru IPA Terpadu menunjukkan bahwa pembelajaran yang dilakukan selama ini masih kebanyakan menggunakan metode ceramah dan hanya menunjukkan gambar-gambar yang ada dalam buku teks sebagai media pembelajaran, jikalaupun mereka menggunakan media audio/visual dan media video hanya sekedar saja tanpa mempertimbangkan karakteristik dan keefektifan media dan materi yang disampaikan, sehingga hasil belajar yang diperoleh siswa juga tidak maksimal. Siswa mengaku kesulitan mendapatkan media pembelajaran yang efektif untuk pelajaran IPA Terpadu di sekolah sehingga siswa merasa kesulitan untuk memahami materi yang disampaikan.

Corel Video studio Pro X4 adalah video editing software yang menawarkan kemampuan untuk membuat dan mengedit video serta menerbitkannya di SkyDrive, Facebook, YouTube, dan Flickr, (Wikipedia.org). Corel Video studio Pro X4 merupakan aplikasi grafis pada microsoft yang sangat mudah pengoperasiannya, sehingga bagi pemula pun dapat menggunakan software ini dan memberikan hasil video yang menarik.
Keuntungan dari pemanfaatan Corel Video studio Pro X4 adalah guru dapat menentukan sendiri obyek/gambar dalam video yang disesuaikan dengan kondisi siswa sehingga diharapkan siswa merasa dekat apa yang disampaikan dalam video. Kedekatan emosi ini dapat meningkatkan minat dan semangat belajar siswa.

Hakikat IPA yang dinyatakan oleh Sri Sulistyorini (2007:9) dapat dipandang dari segi produk, proses dan pengembangan sikap. Artinya, belajar IPA memiliki dimensi proses, dimensi hasil (produk) dan dimensi pengembangan sikap ilmiah. Ketiga dimensi tersebut bersifat saling terkait. Ini berarti proses belajar mengajar IPA seharusnya mengandung ketiga dimensi tersebut.

Sedangkan hakikat IPA menurut Depdiknas (2006) meliputi empat unsur utama yaitu:

1) Sikap: rasa ingin tahu tentang benda, fenomena alam, makhluk hidup, serta hubungan sebab akibat yang menimbulkan masalah baru yang dapat dipecahkan melalui prosedur yang benar; IPA bersifat open ended;

2) Proses: prosedur pemecahan masalah melalui metode ilmiah; metode ilmiah meliputi penyusunan hipotesis, perancangan eksperimen atau percobaan, evaluasi, pengukuran, dan penarikan kesimpulan;

3) Produk: berupa fakta, prinsip, teori, dan hukum;

4) Aplikasi: penerapan metode ilmiah dan konsep IPA dalam kehidupan

Keempat unsur itu merupakan ciri IPA yang utuh yang sebenarnya tidak dapat dipisahkan satu sama lain. Secara umum Ilmu Pengetahuan Alam (IPA) di SMP/MTs, meliputi bidang kajian energi dan perubahannya, bumi antariksa, makhluk hidup dan proses kehidupan, dan materi dan sifatnya yang sebenarnya sangat berperan dalam membantu peserta didik untuk memahami fenomena alam. Ilmu Pengetahuan Alam merupakan pengetahuan ilmiah, yaitu pengetahuan yang telah mengalami uji kebenaran melalui metode ilmiah, dengan ciri: objektif, metodik, sistematis, universal, dan tentatif.

Kesimpulan dari beberapa definisi diatas bahwa IPA adalah sebuah proses memperoleh kebenaran tentang fakta dan 
fenomena alam yang meliputi aspek biologi, fisis dan khemis. Sedangkan hakikat IPA dapat dipandang sebagai sikap, proses, produk serta aplikasi pengetahuan dalam kehidupan seharihari yang keseluruhannya saling terkait secara erat.

Media adalah segala sesuatu yang dapat digunakan untuk menyalurkan pesan dari pengirim ke penerima sehingga dapat merangsang pikiran, perasaan, perhatian, dan minat serta perhatian siswa sedemikian rupa sehingga proses belajar terjadi. (Sadiman,2002:6). Gagne menyatakan bahwa media adalah "berbagai jenis komponen dalam lingkungan siswa yang dapat merangsangnya untuk belajar. Sementara itu, Briggs berpendapat bahwa media adalah segala alat fisik yang dapat menyajikan pesan serta merangsang siswa untuk belajar". Media dalam pembelajaran memiliki fungsi sebagai alat bantu untuk memperjelas pesan yang disampaikan guru. Media juga berfungsi untuk pembelajaran individual dimana kedudukan media sepenuhnya melayani kebutuhan belajar siswa.

Beberapa klasifikasi media pembelajaran yang telah dibuat oleh para ahli untuk memberi batasan pada suatu media. Rudi Bretz ( Sadiman, 2009:20 ) menggolongkan media ke dalam 8 kelas yaitu : (1) Media audio visual gerak, (2) Media audio visual diam, (3) Media audio semi gerak, (4) Media visual gerak, (5) Media visual diam, (6)Media semigerak, (7) Media audio, dan (8) Media cetak.

Media video adalah media visual gerak yang dapat diatur kecepatan geraknya, maka media video efektif bila digunakan untuk membelajarkan pengetahuan yang berhubungan dengan gerak misalnya pada mata pelajaran IPA dapat digunakan untuk menjelaskan konsepkonsep, prinsip-prinsip dalam pelajaran IPA. Bambang Warsito (2008: 33) mengatakan bahwa media video mempunyai potensi meningkatkan pengetahuan, menumbuhkan keinginan motivasi untuk memperoleh informasi lanjut, meningkatkan kemampuan berbahasa, meningkatkan kreativitas /imajinasi, meningkatkatkan berpikir kritis, memicu minat baca.

Model pengembangan Borg Dan Gall memuat panduan sistematika langkah-langkah yang dilakukan oleh peneliti agar produk yang dirancang mempunyai standar kelayakan. Yang diperlukan dalam pengembangan ini adalah rujukan tentang prosedur produk yang akan dikembangkan. Uraian model pengembangan Borg Dan Gall, dijelaskan sebagai berikut; reset dan pengembangan bidang pendidikan (R\&D) adalah suatu proses yang digunakan untuk mengembangkan dan mengesahkan produk bidang pendidikan yang dikenal sebagai siklus $R \& D$, yang terdiri dari: pengkajian terhadap hasil-hasil penelitian sebelumnya yang berkaitan dengan validasi komponen-komponen pada produk yang akan dikembangkan, mengembangkannya menjadi sebuah produk, pengujian terhadap produk yang dirancang, dan peninjauan ulang dan mengoreksi produk tersebut berdasarkan hasil uji coba.

Borg Dan Gall (2005) menyatakan bahwa prosedur penelitian pengembangan pada dasarnya terdiri dari dua tujuan utama, yaitu: (a) pengembangan produk sebagai fungsi pengembangan, dan (b) menguji keefektifan produk sebagai validasi dalam mencapai tujuan. Dengan demikian, konsep penelitian pengembangan lebih tepat diartikan sebagai upaya pengembangan yang sekaligus disertai dengan upaya validasi. Dan dalam pengembangan ini, terdapat 10 langkah umum yang harus ditempuh.

Dengan mencermati pembelajaran dan karakteristik mata IPA Terpadu dengan materi pembelajaran Bahan Kimia Alami dan Buatan di SMP Negeri 1 Silau Laut Kabupaten Asahan, yang masih dianggap belum efektif dan efesien, sejalan dengan zaman teknologi dan informasi yang semakin maju sekarang ini, maka sangatlah penting apabila media pembelajaran berbasis video pada materi pembelajaran dipilih sebagai pendekatan alternatif dalam pengembangan media pembelajaran pada mata pelajaran IPA Terpadu, sehingga dengan adanya media tersebut motivasi, minat dan hasil belajar siswa akan lebih tinggi dibandingkan dengan motivasi, minat dan hasil belajar siswa yang menggunakan media cetak.

Perlu pola perancangan dan penerapan pembelajaran sesuai situasi dan konteks isi pelajaran dengan menggunakan media pembelajaran dalam bentuk pengembangan video pembelajaran pada materi zat aditif pada bahan makanan, untuk membedakan pembelajaran yang mendayagunakan komputer dengan media cetak dalam kegiatan belajar mengajar. Diharapkan setelah siswa selesai mengikuti pembelajaran maka siswa dapat 
mencapai tujuan pembelajaran sebagaimana yang telah ditentukan.

Guna memperoleh program

pembelajaran yang efektif, efisien, dan memiliki daya tarik, peneliti harus mengembangkan media pembelajaran yang tepat dan layak. Media pembelajaran yang dikembangkan peneliti berdasarkan masukan pada kegiatan identifikasi kebutuhan untuk memberikan keyakinan bahwa video pembelajaran yang dikembangkan betul-betul dibutuhkan dan memberikan kemudahan belajar bagi siswa dan guru sebagai user. Maka serangkaian uji coba dan revisi harus dilakukan sebagai prosedur untuk menghasilkan video pembelajaran yang layak.

Hasil yang diharapkan dalam penelitian dan pengembangan ini adalah mengembangkan dan membuat video pembelajaran untuk pembelajaran dengan materi zat aditif pada bahan makanan. Dengan adanya, video pembelajaran ini siswa akan lebih termotivasi belajar dan dapat meningkatkan minat dan ketertarikannya dalam belajar sehingga diharapkan dapat juga meningkatkan hasil belajarnya

\section{METODE}

Penelitian ini dilaksanakan di SMP Negeri 1 Silau Laut Kabupaten Asahan yang terletak di jalan Annisa No.28 Kecamatan Silau Laut Kabupaten Asahan pada siswa kelas VIII semester 1 Tahun Ajaran 2013/2014. Waktu pelaksanaan adalah pada bulan Mei sampai dengan Oktober 2013.

Model pengembangan yang digunakan adalah model pengembangan Borg and Gall (2005) yang dipadu dengan model pengembangan pembelajaran model Dick dan Carey (2005). Adapun langkah-langkah dari tahapan pengembangannya adalah sebagai berikut :

1. Melakukan penelitian pendahuluan, yaitu :

a. Identifikasi kebutuhan pembelajaran dan menentukan standar kompetensi mata pelajaran.

b. Melakukan analisis pembelajaran.

c. Mengidentifikasi karakteristik dan perilaku awal siswa.

d. Menulis kompetensi dasar dan indikator yang akan dicapai oleh siswa. e. Menulis tes acuan patokan

f. Menyusun strategi pembelajaran yang terdiri dari :

- Penjelasan tentang tujuan pembelajaran

- Penjelasan relevansi isi pelajaran baru

- Penjelasan tentang materi pelajaran

- Tes formatif dan umpan balik

- Tindak lanjut

g. Mengembangkan bahan pembelajaran

2. Pembuatan desain video pembelajaran, yang meliputi :

a. Pembuatan naskah

b. Pembuatan storyboard

3. Pengumpulan bahan, yang meliputi :

a. Pembuatan dan pengumpulan gambar (shooting)

b. Pengumpulan audio

4. Mengembangkan dan membuat video pembelajaran

5. Review dan uji coba produk

6. Uji keefektifan produk

Analisis data dalam penelitian ini menggunakan analisis deskriptif kuantitatif. Semua data yang terkumpul dianalisis dengan teknik statistik deskriptif yang secara kuantitatif dipisahkan menurut kategori untuk mempertajam penilaian dalam menarik kesimpulan. Data kualitatif yang berupa pernyataan Sangat Kurang Baik, Kurang Baik, Sedang, Baik dan Sangat Baik diubah menjadi data kuantitatif dengan skala nilai 1 sampai 5 . Hasilnya dirata-ratakan dan digunakan untuk menilai kualitas video pembelajaran. Kriteria akan dikonversikan menjadi nilai dengan skala lima menggunakan Skala Likert yang dianalisis secara deskriptif persentase dengan rumus sebagai berikut (Sugiyono, 2007)

\section{HASIL DAN PEMBAHASAN Hasil}

Proses pertama dalam kegiatan pengembangan ini adalah melakukan analisis kebutuhan di SMP Negeri 1 Silau Laut Kabupaten Asahan dengan cara menebar angket kepada 25 guru dan 64 siswa di kelas. Data analisis kebutuhan tersebut ditampilkan pada Tabel berikut ini : 
Tabel. 1. Data Analisis Kebutuhan

\begin{tabular}{|c|l|l|c|c|c|c|}
\hline \multirow{2}{*}{ No } & \multicolumn{1}{|c|}{ Jenis Informasi } & \multirow{2}{*}{ Jawaban } & \multicolumn{2}{c|}{ Guru } & \multicolumn{2}{c|}{ Siswa } \\
\cline { 4 - 7 } & & & Frek & \% & Frek & \% \\
\hline 1. & $\begin{array}{l}\text { Telah Mengenal atau tidak mengenal } \\
\text { media pembelajaran berbasis audio } \\
\text { visual }\end{array}$ & - Ya & 3 & 12 & 10 & 15,63 \\
\hline 2. & $\begin{array}{l}\text { Menggunakan atau tidak menggunakan } \\
\text { media pembelajaran berbasis audio } \\
\text { visual dalam proses pembelajaran }\end{array}$ & - Tidak & 22 & 88 & 54 & 84,37 \\
\hline 3 & $\begin{array}{l}\text { Memerlukan atau tidak memerlukan } \\
\text { media pembelajaran berbasis audio } \\
\text { visual dalam proses pembelajaran }\end{array}$ & - Tidak & 23 & 92 & 64 & 100 \\
\hline
\end{tabular}

Berdasarkan hasil angket analisis kebutuhan yang disebarkan oleh guru dan siswa diperoleh kesimpulan sebagai berikut:

1. Sebagian besar guru (88\%) maupun siswa $(84,37 \%)$ menyatakan belum mengenal media pembelajaran berbasis audio visual hanya sebagian kecil (12\%) guru dan siswa $(15,63 \%)$ yang menyatakan telah mengenal media tersebut.

2. Sebagian besar guru (92\%) menyatakan tidak menggunakan media pembelajaran berbasis audio visual dalam proses pembelajaran dan seluruh siswa (100\%) menyatakan tidak pernah menggunakan media tersebut.

3. Sebagian besar guru (88\%) menyatakan memerlukan media pembelajaran berbasis audio visual dalam proses pembelajaran dan seluruh siswa (100\%) menyatakan memerlukannya.

Tabel.2. Rangkuman Persentase Rata-Rata Hasil Penilaian Terhadap Media Pembelajaran Berbasis Multimedia Materi Zat Aditif Pada Bahan Makanan

\begin{tabular}{|l|l|c|c|}
\hline No & \multicolumn{1}{|c|}{ Responden } & $\begin{array}{c}\text { Persentase } \\
\text { Rata-rata }\end{array}$ & Kriteria \\
\hline 1 & Ahli materi pembelajaran & $85,47 \%$ & Sangat Baik \\
\hline 2 & Ahli media pembelajaran & $87,77 \%$ & Sangat Baik \\
\hline 3 & Siswa pada uji coba perorangan & $91,43 \%$ & Sangat Baik \\
\hline 4 & Siswa pada uji coba kelompok kecil & $92,87 \%$ & Sangat Baik \\
\hline 5 & Siswa pada uji coba lapangan & $97,23 \%$ & Sangat Baik \\
\hline & Rata-Rata & $\mathbf{9 0 , 9 5 \%}$ & Sangat Baik \\
\hline
\end{tabular}

Hasil penilaian terhadap media pembelajaran berbasis audio visual (video) materi zat aditif pada bahan makanan pada uji coba lapangan pada 32 siswa semester 1 (satu) SMP Negeri 1 Silau Laut kelas VIII menunjukkan bahwa produk yang dikembangkan sangat baik atau layak digunakan dan tidak ada saran perbaikan yang disampaikan pada uji coba lapangan ini sehingga tidak dilakukan revisi IV.

Berdasarkan analisis data hasil evaluasi ahli materi dan ahli media pembelajaran, peneliti melakukan beberapa revisi. Hasil revisi tersebut dapat dilihat pada penjelasan di bawah ini:

a. Mengganti logo tut wuri handayani dengan cuplikan gambar-gambar penunjang sebagai opening video pembelajaran.

b. Mengganti gambar latar belakang menjadi lebih bervariasi.

c. Memperbaiki jenis, warna dan ukuran huruf yang tidak jelas.

d. Memperbaiki gambar yang tidak sesuai dengan materi

e. Memberi pengantar peta konsep untuk materi selanjutnya

f. Mengganti musik yang terlalu kontras 
g. Memperbaiki urutan penyajian

h. Menambahkan soal latihan pada setiap sub pokok bahasan

i. Memperbaiki tampilan dan durasi rangkuman

j. Menampilkan sumber gambar yang diunduh dari internet

k. Mengurangi durasi video

1. Menampilkan kerabat kerja pada ending video

\section{Pembahasan}

Pengembangan media pembelajaran berbasis audio visual (video) dilakukan berdasarkan tahapan sebagaimana yang terdapat dalam prosedur. Hasil pengembangan selanjutnya dilakukan uji kelayakan atau validasi oleh ahli yang telah ditentukan. Berdasarkan hasil validasi yang dilakukan, produk media pembelajaran berbasis audio visual (video) dinyatakan layak untuk diteruskan dalam uji coba lapangan. Media pembelajaran berbasis audio visual (video) yang dikembangkan telah memenuhi standar berdasarkan perancangan standar pengembangan media pembelajaran, dan standar materi pembelajaran. Dari angket yang disampaikan kepada ahli media pembelajaran memberikan tanggapan $87,77 \%$, bahwa media pembelajaran berbasis audio visual (video) layak digunakan karena telah memenuhi prinsip-prinsip dan kriteria pengembangan media audio visual. Sementara itu, Ahli Materi Pembelajaran memberikan tanggapan 85,47 \%, bahwa media pembelajaran berbasis audio visual (video) layak digunakan karena telah memuat materi dan kriteria penyampaian yang memenuhi standar penyampaian pesan kepada siswa. Ahli Desain Pembelajaran memberikan tanggapan $82,88 \%$, bahwa media pembelajaran berbasis audio visual (video) layak digunakan karena telah didesain sedemikian rupa dan telah memenuhi standar desain pembelajaran.

Penelitan pengembangan produk yang dilakukan ini diarahkan untuk menghasilkan suatu produk berupa media pembelajaran berbasis audio visual (video) materi zat aditif pada bahan makanan untuk siswa SMP Negeri 1 Silau Laut kelas VIII semester I (satu)) yang digunakan untuk meningkatkan proses pembelajaran maupun kompetensi siswa.

Aspek yang direvisi dan disempurnakan berdasarkan analisis data dan uji coba serta masukan dari ahli materi, ahli media pembelajaran, dan siswa selaku pengguna media pembelajaran berbasis audio visual (video) ini, bertujuan untuk menggali beberapa aspek yang lazim dalam proses pengembangan suatu produk. Variabel-variabel media pembelajaran memiliki nilai rata-rata sangat baik. Adapun variabel media pembelajaran yang dinilai meliputi kelayakan isi, penyajian, kebahasaan, pemrograman, tampilan dan pemanfaatan.

Beberapa kegunaan dan manfaat dalam penggunaan media pembelajaran berbasis audio visual (video) materi zat aditif pada bahan makanan sebagai berikut: (1) materi mudah dipahami karena konsep yang disajikan direncanakan untuk mempermudah siswa dan sistematis, (2) media pembelajaran berbasis audio visual (video) memberi kesempatan siswa untuk belajar sesuai dengan kecepatan masingmasing individu, (3) belajar lebih cepat dan menarik sehingga tidak menimbulkan kebosanan karena dilengkapi dengan gambargambar dan animasi serta soal latihan yang bervariasi. (4) adanya kesempatan dalam menjawab soal pada waktu tes jika jawaban dianggap salah dengan tujuan agar siswa dapat memahami materi yang telah dipelajari, (5) media pembelajaran berbasis audio visual (video) ini juga dapat digunakan sebagai alternatif media pembelajaran secara konvensional maupun individual, mengatasi jarak dan waktu, mampu menggambarkan peristiwa-peristiwa masa lalu secara realistis dalam waktu yang singkat, dapat diulang-ulang bila perlu untuk menambah kejelasan, pesan yang disampaikannya cepat dan mudah diingat, megembangkan pikiran dan pendapat para siswa, mengembangkan imajinasi, memperjelas hal-hal yang abstrak dan memberikan penjelasan yang lebih realistik, mampu berperan sebagai media utama untuk mendokumentasikan realitas yang akan didiskusikan di dalam kelas.

Dari hasil pengolahan data penelitian yang dilakukan, terdapat rata-rata hasil belajar IPA siswa pada materi zat aditif pada bahan makanan yang dibelajarkan dengan menggunakan media pembelajaran berbasis audio visual (video) yaitu skor rata-rata sebesar 15,83 dengan persentase ketuntasan 83,39 \%, sedangkan nilai KKM IPA Terpadu kelas VIII siswa SMP Negeri 1 Silau Laut Kabupaten Asahan adalah 70. Setelah melakukan uji efektifitas produk maka diperoleh bahwa 
produk media pembelajaran berbasis audio visual (video) yang dikembangkan memiliki efektifitas sebesar 81,58 dengan kategori sangat baik Dari data ini membuktikan bahwa media pembelajaran berbasis audio visual (video) ini layak dan efektif digunakan dalam meningkatkan kompetensi dan pengetahuan siswa.

Penggunaan media pembelajaran berbasis audio visual (video) memungkinkan siswa untuk lebih mudah memahami zat aditif pada bahan makanan karena dari media pembelajaran ini memungkinkan siswa untuk berinteraksi langsung, memiliki gambargambar, animasi, sound background dan soal latihan, sehingga setiap siswa tidak kesulitan lagi dalam membayangkan dalam hal membaca gambar karena didalam media ini telah dijelaskan secara detail. Selain itu, media pembalajaran ini sangat praktis, karena media ini dapat dibawa oleh siswa dan dapat dipelajari dirumah.

\section{PENUTUP}

\section{Simpulan}

Berdasarkan hasil dan pembahasan penelitian pengembangan media pembelajaran berbasis multimedia yang dilakukan maka dapat disimpulkan sebagai berikut:

1) Pengembangan media pembelajaran berbasis audio visual memang sangat dibutuhkan oleh guru dan siswa dalam proses pembelajaran. Hasil penelusuran dari angket yang disebar ditemukan bahwa $88 \%$ dari guru menyatakan membutuhkan media pembelajaran dalam proses pembelajaran agar proses pembelajaran berjalan lebih efektif, dan $100 \%$ siswa menyatakan membutuhkan media video agar dapat mereka jadikan sebagai sarana pembelajaran secara individual maupun klasikal

2) Hasil validasi dari ahli materi terhadap media pembelajaran berbasis multimedia materi zat aditif pada bahan makanan yang dikembangkan menunjukkan bahwa; (1) kelayakan isi materi pembelajaran dinilai sangat baik dengan persentase rata-rata sebesar $88,00 \%$, (2) kelayakan penyajian pembelajaran dinilai sangat baik dengan persentase rata-rata sebesar $89,17 \%$, (3) kelayakan kebahasaan dinilai sangat baik dengan persentase rata-rata sebesar 86,15 $\%$. Dengan demikian media pembelajaran berbasis multimedia materi zat aditif pada bahan makanan yang dikembangkan dengan menggunakan Corel Video studio Pro X4 secara keseluruhan $(87,77 \%)$ termasuk dalam kategori "Sangat Baik".

3) Hasil validasi dari ahli media pembelajaran terhadap media pembelajaran berbasis multimedia materi zat aditif pada bahan makanan dikembangkan dengan menggunakan program Corel Video studio Pro X4 menunjukkan bahwa; (1) kelayakan tampilan media pembelajaran dinilai sangat baik dengan persentase ratarata $85,38 \%$, (2) kelayakan pemrograman media dinilai sangat baik dengan persentase rata-rata sebesar 85,55 \%. Berdasarkan hasil validasi tersebut disimpulkan bahwa media pembelajaran berbasis multimedia materi zat aditif pada bahan makanan yang dikembangkan termasuk dalam kriteria sangat baik $(85,47 \%)$, sehingga dapat diterima dan layak digunakan dalam proses pembelajaran.

4) Menurut tanggapan siswa kelas VIII SMP Negeri 1 Silau Laut Kabupaten Asahan pada uji coba perorangan dinyatakan bahwa media pembelajaran berbasis multimedia yang dikembangkan dengan program dan Corel Video studio Pro X4 termasuk kategori sangat baik dimana aspek materi pembelajaran dinilai dengan persentase rata-rata sebesar $100,00 \%$ dan kelayakan tampilan penyajian sebesar $95,15 \%$, serta aspek kemanfaatan media sebesar 92,22 \%. Berdasarkan hasil uji coba perorangan tersebut disimpulkan bahwa media pembelajaran berbasis multimedia materi zat aditif pada bahan makanan yang dikembangkan termasuk dalam kriteria sangat baik (95,79\%), sehingga dapat diterima dan layak digunakan dalam proses pembelajaran.

5) Menurut tanggapan siswa kelas VIII SMP Negeri 1 Silau Laut Kabupaten Asahan pada uji coba kelompok kecil dinyatakan bahwa media pembelajaran berbasis multimedia yang dikembangkan dengan program Corel Video studio Pro X4 termasuk kategori sangat baik $(92,87 \%)$, dimana aspek materi pembelajaran dinilai dengan persentase rata-rata sebesar 94,81 $\%$ dan kelayakan tampilan penyajian 
sebesar $92,32 \%$, serta aspek kemanfaatan media sebesar $91,48 \%$.

6) Menurut tanggapan siswa siswa kelasVIII SMP Negeri 1 Silau Laut Kabupaten Asahan pada uji coba lapangan dinyatakan bahwa media pembelajaran berbasis multimedia yang dikembangkan dengan program Corel Video studio Pro X4 termasuk kategori sangat baik $(97,23 \%)$, dimana aspek materi pembelajaran dinilai dengan persentase rata-rata sebesar 98,13 $\%$ dan kelayakan tampilan penyajian sebesar 98,13\%, serta aspek kemanfaatan media sebesar 95,42\%.

7) Media pembelajaran yang dikembangkan peneliti layak untuk digunakan sebagai media pembelajaran IPA untuk siswa kelas VIII SMP Negeri 1 Silau Laut Kabupaten Asahan semester 1 (satu), karena memiliki nilai rata-rata $(81,58)$ yang lebih tinggi dari nilai $\mathrm{KKm}$ (70) yang ditentukan.

8) Media pembelajaran berbasis multimedia memiliki keefektifan sebesar 81,58\% dengan kategori sangat tinggi.

\section{Saran}

Berdasarkan hasil temuan yang telah diuraikan pada kesimpulan serta implikasi hasil penelitian, berikut ini diajukan beberapa saran yaitu:

a. Media pembelajaran berbasis multimedia pada mata pelajaran IPA memerlukan adanya TV, VCD/DVD, komputer sehingga hendaknya komputer yang ada dilaboratorium komputer di setiap sekolah ditambah atau dilengkapi sesuai kebutuhan siswa.

b. Media pembelajaran ini adalah sebagai salah satu alat untuk membantu dalam proses penyampaian pembelajaran, keberadaan guru masih sangat diperlukan sebagai fasilitator dan siswa tetap terlibat aktif dalam proses pembelajaran.

c. Agar hasil produk lebih maksimal dan layak digunakan lebih jauh lagi, maka diperlukan pengembang yang terdiri dari: ahli pengembang kurikulum, ahli bidang studi dan ahli materi yang profesional, ahli media, dukungan dana, sarana dan waktu yang tersedia, dan kemampuan saranaprasarana dalam produksi media yang memadai. d. Diharapkan penelitian atau uji coba lebih lanjut terhadap populasi yang lain untuk mendapatkan hasil yang lebih akurat.

e. Dengan alasan keterbatasan waktu dan dana peneliti, sehingga masih banyak beberapa pengaruh-pengaruh yang belum terkontrol maka perlu kiranya dilakukan penelitian lebih lanjut pada sampel yang lebih representatif.

\section{KEPUSTAKAAN}

AECT. 1977. Defenisi Teknlogi Pendidikan (Satuan tugas defenisi dan terminologi AECT). Jakarta : Rajawali.

Arief, Sadiman, dkk. 2002. Media Pendidikan. Jakarta: PT Raja Grafindo Persada

Arikunto, S. 2007. Penelitian Tindakan Kelas. Jakarta : Bumi Aksara.

Arsyad, A. 2002. Media Pengajaran. Jakarta : Raja Grafindo Persada . 2010. Media Pengajaran. Jakarta : Raja Grafindo Persada

Bambang, Warsita. 2008. Teknologi Pembelajaran Landasan dan Aplikasinya. Jakarta : Rineka Cipta.

Borg, W. \& V, Gall, M.D. 1983. Educational research, an Introduction, $4^{\text {th }}$ ed. New York : Longman

Dahar. 1996. Model-model Mengajar. Bandung : CV. Diponegoro

Depdiknas. (2008). Kamus Besar Bahasa Indonesia. Jakarta: Balai Pustaka.

Dick, Walter dan Lou Carey. 1990. The Systematic Design of Instruction (3ed). Florida : Harper Collins Pub.

Dimyati. 2005. Belajar dan Pembelajaran. Jakarta : Depdikbud

Djamarah, Syaiful Bahri. 2002. Strategi Belajar Mengajar. Jakarta : Rineka Cipta

Driscoll, M. 2002. Web Based Training ; Creating E-Learning Experiences. San Fransisco : Jossey Bass/Pfeiffer A Willey Company.

Mulyasa. 2003. Manajemen Berbasis Sekolah. Bandung: Remaja Rosdakarya.

Eshach Haim. 2006. Science Literacy In Primary Schools And Pre-Schools. Netherlands : Springer.

Fathurrohman, P, dkk. 2007. Strategi Belajar Mengajar. Bandung : Refika Aditama.

Hamalik, Oemar. 2007. Dasar-dasar Pengembangan Kurikulum. Bandung : PT. Remaja Rosdakarya 
Heinich, Robert, et, Al. 1996. Instructional Media and Technologies for learning (5 ed). New Jersey : Simon \& Schuster Company Engelewood Cliffs.

Henyat Soetomo. 1993. Pembinaan dan Pengembangan Kurikulum, Jakarta:

Bumi Aksara.

Iskander,Magued. 2007. Innovations in Elearning, Instruction Technology, Assessment, and Engineering Education. USA : Springer.

Jerrold, Kemp, dkk. 1985. Planning and Producing Instructional Media. New york : Harper \& Row.

Latuheru, John D.1988. Media Pembelajaran Dalam Proses Belajar Mengajar Masa Kini. Jakarta : Depdikbud \&P2 LPTK

Lingin. 2012. Pengembangan Media Pembelajaran Interaktif Pada Mata Pelajaran Geografi. Tesis. Unimed. Medan

Meier, Dave. 2005. The Accelerated Learning. Bandung : Kaifa

Mulyani, Isti. 2012. Pengaruh Penggunaan Media Pembelajaran Berbasis Video Terhadap Prestasi Belajar Siswa Pada Mata Pelajaran IPA kelas VIII di SMP Negeri 2 Pracimantoro Wonogiri. Tesis : UNY

Munadi, Yudhi. 2008. Media Pembelajaran, Sebuah Pendekatan Baru. Ciputat : Gaung Persada Press

Muslich, M. 2007. KTSP Pembelajaran Berbasis Kompetensi dan Kontekstual. Jakarta : Bumi Aksara.

Osborn, J. \& Dillon, J. 2008. Science Education in Europe : Critical reflection. A Report to the Nuffield Foundation. London : King's Collage.

Prasetyo, Sigit. 2007. Pengembangan Pembelajaran dengan Menggunakan Multimedia Interaktif untuk Pembelajaran yang Berkualitas. Semarang : UNNES.

Putro, Anggoro, D.2012. Upaya Peningkatan Prestasi Belajar Sistem Pemindah Tenaga Kelas 2 Melalui Penggunaan Media Video Pembelajaran Dan Animasi. Skripsi. IKIP Veteran Semarang

Rahardjo. 1988. Media pembelajaran. Jakarta CV : Rajawali

Sadia, W. dkk. 2004. Landasan Konseptual Pengelolaan
Mengajar.Materi Perkuliahan Landasan Pembelajaran Program S2 Penelitian dan Evaluasi Pendidikan IKIP Negeri Singaraja.

Sadiman, Arief S. dkk. 2002. Media Pendidikan. Jakarta : PT. Raja Grafindo Persada.

Saiful, Sagala. 2007. Konsep dan Makna Pembelajaran. Bandung : Alfabeta

Salim, Peter. 1996. The Contemporary EnglishIndonesian Distionary. Jakarta : Modern English Press.

Salisbury, D.F. 1996. Five Technologies for educational Change. New Jersey : Educational Technology Publications. Inc.

Sanjaya, W. 2008. Strategi Pembelajaran Berorientasi Standar Proses Pendidikan. Jakarta: Kencana.

Satyasa, I Wayan. 2007. Metodologi Penelitian Tindakan Kelas. Jakarta : UT\

Setyosari, Punaji \& Sihkabuden. 2005. Media Pembelajaran. Malang : Penerbit Elang Mas

Simamora,Roymond H. 2009. Pendidikan dalam Keperawatan.Jakarta : Penerbit Buku Kedokteran EGC

Smaldino, Sharon E, dkk. 2008. Instructional Technology and Media for Learning. Ohio : Pearson Merrill Prentice Hall.

Sudjana, Nana. 2007. Media Pembelajaran. Bandung: Sinar Baru Algensindo

Sukardi. 2007. Metodelogi Penelitian Pendidikan. Jakarta : Bumi Aksara.

Sugiyono. 2007. Metode Penelitian Pendidikan. Bandung: Alfabet

Sumaji, dkk. 1998. Pendidikan Sains yang Humanistis. Yokyakarta : Kanisius

Suparman, Atwi. 1997, Desain Intruksional, Jakarta : PAU PPAI Universitas Terbuka

Suryabrata, Sumadi. 2005. Psikologi Pendidikan. Jakarta : PT. Raja Grafindo Persada

Syamsuddin , Abin Makmun. 2003. Psikologi Pendidikan. Bandung: Rosda Karya Remaja.

Trianto. 2010. Model Pembelajaran Terpadu. Jakarta : Sinar Baru Algensindo . 2007. Model Pembelajaran Terpadu dalam Teori dan Praktek. Jakarta : Prestasi Pustaka. 